\title{
Biodigester Development and Kinetic Study of Biogas Production from Biomass
}

\author{
Sherwin T. Sepe, Melito A. Baccay, Baba E. Jibril, and Yahya M. Al Wahaibi
}

\begin{abstract}
This study is focused on the development of biodigester, and the mathematical modeling of biogas production with $50 \%$ and $80 \%$ by volume of monosubstrate of Hay, Corn and Cow Manure.

The mathematical model was developed using the designed and fabricated $2750 \mathrm{~cm}^{3}$ digester within 31 days which was proven to be significantly related to the density of gas and temperature. The 50\% by volume Hay, Corn and Cow Manure revealed a significant correlation coefficient of determination $\left(R^{2}\right)$ values of $0.5294,0.1271$ and 0.0702 respectively and 0.3685 , 0.1187 and 0.2841 for $80 \%$ by volume monosubstrate samples with respect to the density of gas. However, it was found out that the density of gas significantly increases as the $\% \mathrm{CH}_{4}$ yield decreases or vice versa (except for $50 \%$ by volume monosubstrate Cow manure sample) for Hay and Cow Manure monosubstrate samples and the density of gas of Corn sample increases together with its increasing $\% \mathrm{CH}_{4}$ yield. The significant relationship among the samples towards temperature and time is said to be proportional to each other for both Hay and Cow Manure and opposite to the Corn sample.

Furthermore, it was established that the significant effect of density of gas and temperature with time considering $50 \%$ by volume of Hay and Corn monosubstrate samples and $80 \%$ by volume of Hay, Corn and Cow manure monosubstrate samples lead to the development of the modeled equation following the $2^{\text {nd }}$ order reaction.
\end{abstract}

Index Terms-Biodigester development, kinetic study, biogas and biomass.

\section{INTRODUCTION}

Environmental degradation and increasing prices of conventional energy resources are driving the global shift towards the renewable [1].

The advantages of using biogas reactor system are under greenhouse gas initiative, minimize unpleasant odor, prevent

Manuscript received August 8, 2013; revised November 23, 2013. This work was supported by the Department of Petroleum and Chemical Engineering of the College of Engineering, Sultan Qaboos University, Department of Engineering of Ibra College of Technology, Ibra, Oman and the Philippine Women's University, Manila, Philippines. The study is entitled Biogas Development and Kinetic Study of Biogas Production from Biomass.

Sherwin T. Sepe was with the Department of Sciences under Chemistry Section of Higher College of Technology, Muscat. He is now with German University of Technology, Muscat Sultanate of Oman (tel.: +968-97722485; e-mail: sherwin.sepe@gutech.edu.om,s_sepe_6300@yahoo.com).

Melito A. Baccay is with the College of Engineering of Technological University of the Philippines, Manila, Philippines (e-mail: melbaccay@yahoo.com).

Baba E. Jibril is with the Petroleum and Chemical Engineering Department of Engineering, Sultan Qaboos University (e-mail: baba@squ.edu.om).

Yahya M. Al Wahaibi is with the Department Head of Petroleum and Chemical Engineering of the College of Engineering, Sultan Qaboos University, Sultanate of Oman (e-mail: engpce@squ.edu.om). disease transmission, and generate heat, power and by product such as solid and liquid fertilizers [2].

Biogas technology has been introduced in 1980, thus it is not a new innovation around the world [3]. However, its success was sluggish due to various contains such as lack of technical expertise, misfunction of biogas reactor enough to establish liability due to the proportion of the yield and reactor size, non-user friendly design, manually handling or organic load, and in enticing or expelling sludge from reactor.

Therefore, in-depth study of reaction kinetics that will connect the discrepancy of the actual fabrication between the reactor and the production yield of the biogas is highly regarded [4]. It was agreed by Widodo and Nurhasanah [5] because by introducing the new approaches for its development were explicitly required. And the researcher come up the idea of investigating the factors affecting the rate of biogas yield of energy crops and animal wastes slurry and develop a mathematical model of the rate of kinetics based on the determined order of reaction to optimize industrial production of the gas.

\section{OBJECTIVES AND SIGNIFICANCE OF THE STUDY}

The study focused on the development of a biodigester with kinetic modeling of biogas production from biomass.

Specifically, it aimed to achieve the following sub-objectives: (1) Characterize the following feed materials, in terms of $\mathrm{pH}$, total solids, (TS), and volatile solids (VS) (a) Hay, (b) Corn, and (c) Cow Manure substrate; (2) Establish the properties of Hay and Corn substrate in terms of (a) Crude Protein (XP), (b) Crude Fat (XL), and (c) Crude Fiber (XF); (3) Determine the biogas yield of the monosubstrate of Hay, Corn and Cow manure in terms of the following: (a) density of the influent, (b) density of the biogas, (c) temperature, (d) concentration of carbon dioxide, (e) maximum biogas yield, and (f) the no. of days required of producing maximum biogas yield; and ( $g$ ) Develop the kinetic model equation for the production of biogas in a batch reactor.

\section{MethodS AND DESIGN}

This research design utilized experimental method in determining the desired analytical evaluation to develop a kinetic modeled equation that was used in designing a biogas reactor of the same influent.

\section{A. Biogas Digester and Its Fabrication}

The reactor that was used in this study was fabricated and assembled guided by the design layout of the biodigester (Fig. 1) at the Workshop Area of the Mechanical Section of Engineering Department of Ibra College of Technology, Ibra, Sultanate of Oman. 


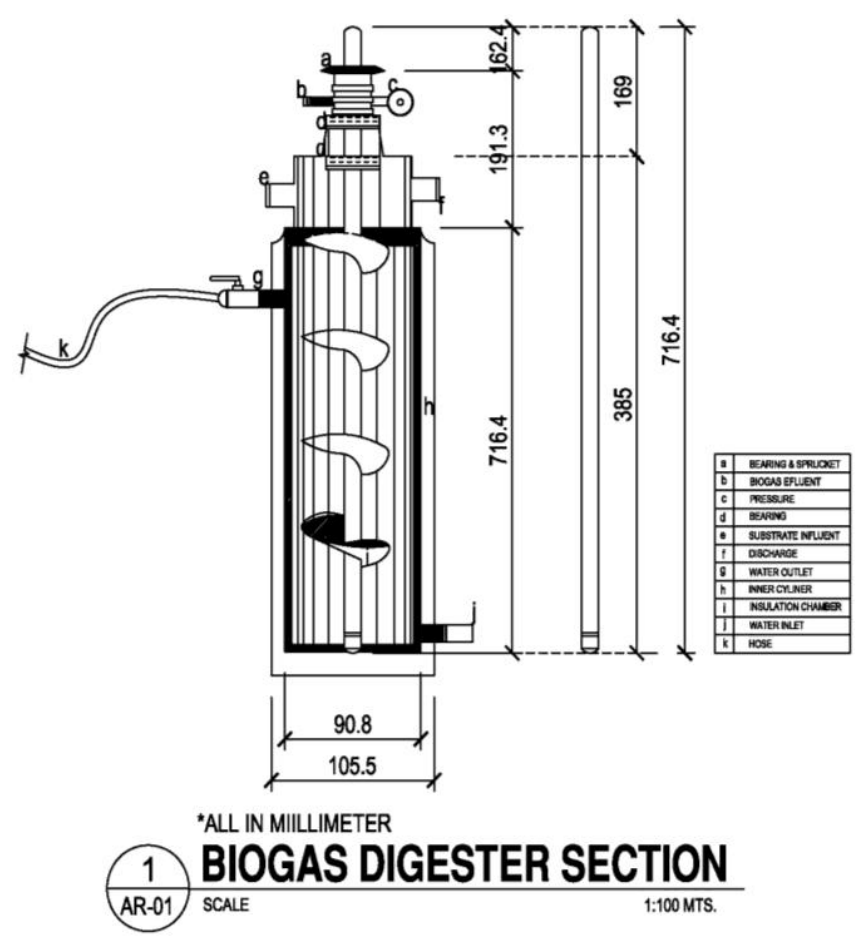

Fig. 1. Layout of the Biodigester.

The design of the reactor was ideally crafted based on the availability of materials, conditions of the process and the parameters set for an anaerobic digestion of samples on this study.

The raw materials for fabrication of the reactor were made of cylindrical cast iron metal that has a diameter ranging from 4 and 7 inches for the inner digester and water jacket. The actual fabrication of the reactor was divided into five phases. These phases were preparations of (1) the insulator cylinder, (2) the digestion chamber, (3) the cover and support of the reactor shaft, (4) the agitator, and (5) the assembly of the reactor.

\section{B. Insulator Cylinder}

The outer cylinder of the reactor served as an insulator of the digester. At first, the cylindrical cast iron was lathed and polished to remove undesirable edges and make it proportioned with the height of the other reactor. This was followed by boring the opposite side of the cylinder using drilling machine. The holed sides served as the water inlet and outlet. Then, the base of the cylinder was covered using a fabricated circular plate proportional to the outer diameter of the cylinder. This circular plate was attached by welding it. And the tendency of leaks was tested by putting water on it for 5 hours.

\section{Digestion Chamber}

The digestion chamber is the inner cylindrical tube covered by the insulator cylinder. This tube contained the samples that were digested in this study. The same with the preparation of insulator cylinder, the polishing the edges and the measuring the exact dimensions routine of the fabrication were observed at all times. The bottom of the chamber was fitted with a metal plate cover proportioned to the diameter of the chamber. Before the cover was attached to the bottom the chamber, a slot at the center was installed to hold the agitator's shaft from wagging during operation. All parts of the chamber including the holder of the from the insulator cylinder were attached by welding

\section{Reactor's Cover and Support of Reactor's Shaft}

The reactor's cover was also used to support the agitator's shaft from rotating. The cover has two parts, the upper and the lower part. The lower part of the cover was directly attached to the digestion chamber and it was partially sealed using an M-seal cement. The cover was open every after digestion for maintenance and cleaning. This part had two holes, one for the loading influent and the other one was for the effluent section. These holes were sealed using a 2 inches valve control for easy loading and freeloading. The upper part of the cover had a two support system for the agitator's shaft. At the lower portion of this part, the opposite direction holes were bored to allow the biogas to pass though it for gas sampling collection. And exactly at the center, the sealed bearing was installed to support and allow the shaft to freely rotate during operation. At the upper part of the same metal cover, another bearing was installed fitted within a bushing with rubber O-ring to avoid gas leaks. The upper and the lower part of the reactor's were joined by welding and tested for the provision of gas leaks.

\section{E. Reactor's Agitator}

The reactor's agitator was composed of shaft, four spiral propeller, screw lock, and the sprocket in a bushing. A metal rod was cut using a power saw and lathed to obtain the desirable dimension referring to the size of the inner diameter of the bearing used. When the shaft was prepared, the four spiral propeller was installed with equal distances followed by the making of the screw for the lock of the shaft.

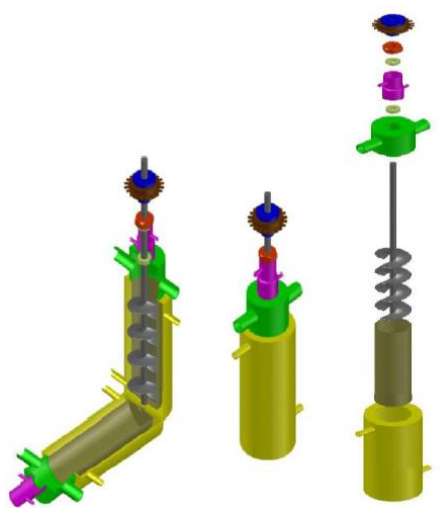

Fig. 2. Assembled reactor.

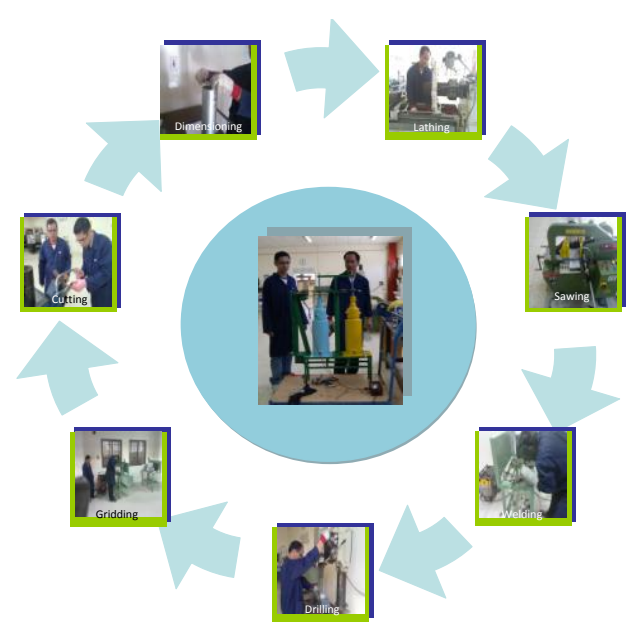

Fig. 3. Summary of the assembling process. 


\section{F. Assembly of Reactor}

The assembly of the reactor was done after all parts were prepared. The order of assembly following the order: (1) Insulator cylinder; (2) Digestion chamber; (3) Reactor's agitator; (4) Reactor's cover; (5) Upper bearing; (6) Screw lock; and (7) Sprocket with bushing. The assembled, exploded parts and the summary of assembly of the reactor are shown in Fig. 2 and Fig. 3.

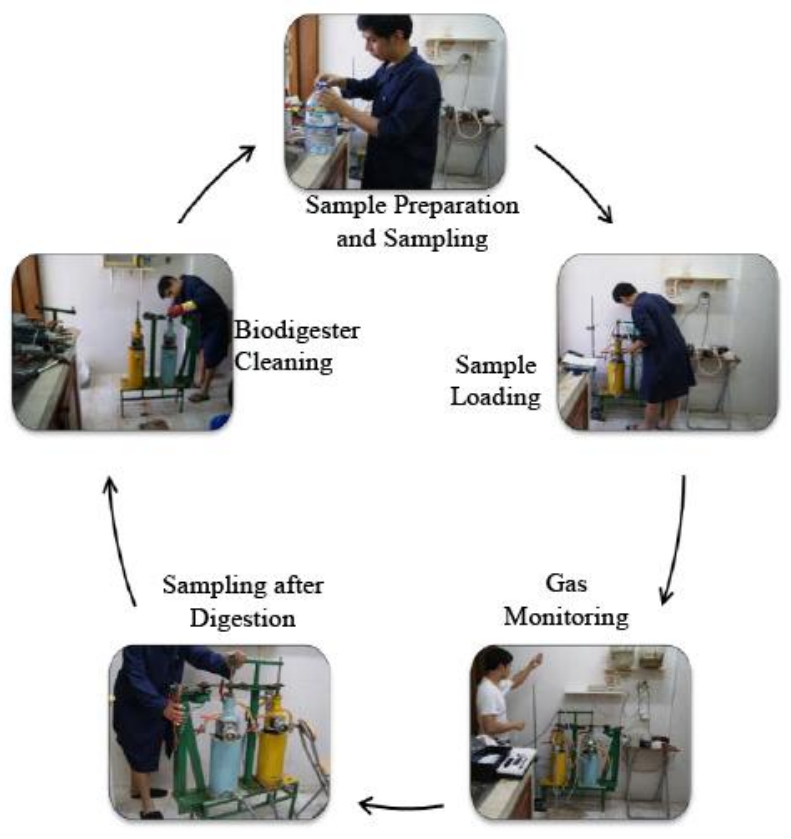

Fig. 4. Digestion monitoring process.

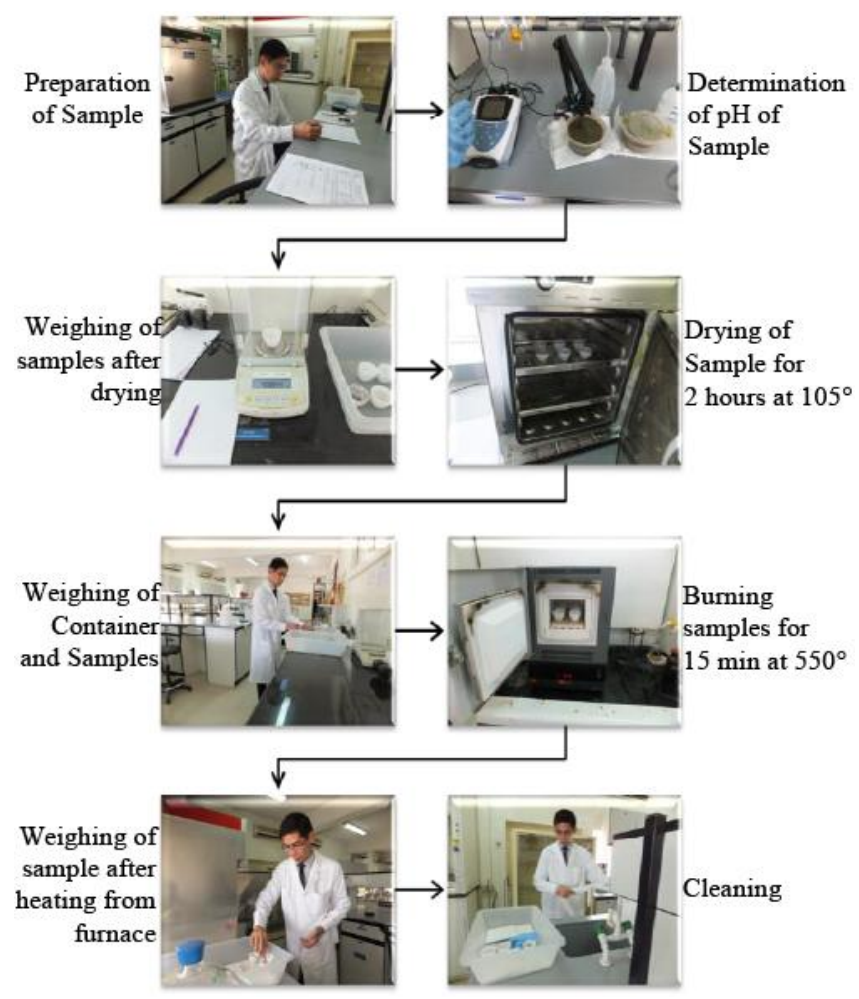

Fig. 5. Experimental determination of sample parameters.

\section{G. Gathering of Data}

The gatherings of data were conducted before, during and after the loading of the sample to the reactor. Before loading the samples to the reactor, the following analyses were carried out in meeting the required standard: (1) total solids; (2) total volatile solids; (3) density of the effluent; (4) $\mathrm{pH}$ value of the crude sample in $50 \%$ and $80 \%$ by volume of Hay, Corn and Cow Manure; and (5) crude fat, protein and carbohydrates for energy crops (Hay and Corn) samples analysis (the sample was sent to the Bureau of Plant Industry, Manila, Philippines for analysis).

During the digestion, the following parameters were monitored every day (at night time) for the duration of 31 days: (1) actual pressure; (2) actual temperature; (3) \% composition of methane; (4) \% composition of carbon dioxide; and (5) density of the gas. (Refer to Fig. 4)

After the digestion, the following variables were also determined like (1) total solids, (2) total volatile solid, and (3) $\mathrm{pH}$ value of the $50 \%$ and $80 \%$ by volume samples of Hay, Corn, and Cow Manure. (Refer to Fig. 5)

There were two color coded reactors (yellow and blue) that were carrying the process of digestion. One reactor was used for the monodigestion of $50 \%$ by volume (yellow color) and the other reactor was carrying the $80 \%$ by volume (blue color) samples of Hay, Corn and Cow Manure respectively and simultaneously. Based on the three samples, the experimentation processes were divided into three (3) stages. On the first stage, the dried sample of Hay was mixed with $50 \%$ water by volume using the yellow reactor simultaneously with the $80 \%$ by volume of Hay sample in the blue reactor. The $50 \%$ and $80 \%$ by volume prepared samples of Hay were digested simultaneously in 31 days period. The second and third stages of digestion were treated similarly with the $1^{\text {st }}$ stage of digestion but it uses Corn and Cow Manure instead of Hay. The setup of two reactors with a volume of $2750 \mathrm{~cm}^{3}$ each was connected to gas analyzer for constant gas monitoring. The batch experiment was carried out in mechanically stirred tank biodigester with heated water jacket at 35 to $40{ }^{\circ} \mathrm{C}$ (mesophilic temperature). The agitation or stirring time was set to 5 hours interval in one day with 1 hour agitation each period every day. The monitoring apparatus such as thermometer, pressure gauge and the like was installed in the setup before the digestion process started. The produced biogas was collected using gas flow meter and automatically analyzed every night for the duration of 31 days with respect to the gas components $\mathrm{CH}_{4}$, and $\mathrm{CO}_{2}$. And the biogas volume was collected within mesophilic conditions ( 35 to $40{ }^{\circ} \mathrm{C}, 760 \mathrm{~mm} \mathrm{Hg}$ or $1 \mathrm{~atm}$ ). The biogas yield as a function of time, density of effluent solids, density of gas, temperature, pressure, total solids, total volatile solids of $50 \%$ and $80 \%$ by volume of energy crops (Hay and Corn) and Cow manure samples including crude fats, proteins and carbohydrates (in case of Hay and Corn) were statistically correlated. The density of biogas was determined during the digestion as a function of temperature, pressure with the empty space (as a volume) of the reactor. And the density calculation was treated ideally in this study. The maximum biogas yield and the reaction rate constant were determined graphically by plotting time versus density of gas, natural logarithm of density of gas and the fraction of gas density. The resulting data were tabulated and treated accordingly in preparation of the development of the kinetic model. And after gathering all the experimental data, the synthesis of the mathematical kinetic modeling was developed. 


\section{RESUlts AND ANALYSIS}

\section{A. Characteristics of Feed Materials}

The $\mathrm{pH}$ Values. The $\mathrm{pH}$ of the Hay, Corn and Cow Manure as a monosubstrate samples is tabulated in Table I.

As presented in the table, the average $\mathrm{pH}$ of the $50 \%$ and $80 \%$ by volume Hay sample before digestion are 6.7 and 6.8 respectively and 6.8 and 6.9 after digestion. This shows that the samples remain slightly acidic to neutral even after the digestion is done.

The average $\mathrm{pH}$ of the $50 \%$ and $80 \%$ by volume Corn sample before digestion are 6.2 and 6.2 respectively and 5.4 and 3.9 after digestion. It appears that the corn sample became more acidic after 31 days of digestion.

The average $\mathrm{pH}$ of the $50 \%$ and $80 \%$ by volume of Cow Manure sample before digestion are 8.6 and 8.4 respectively and 7.6 and 7.5 after digestion. These $\mathrm{pH}$ values mean that the sample turned to slightly basic slurry from a slightly acidic origin.

TABLE I: THE AVERAGE PH VALUES BEFORE AND AFTER DIGESTION
\begin{tabular}{|c|c|c|c|}
\hline $\begin{array}{c}\text { Percent of } \\
\text { Solid Sample } \\
\text { by volume }\end{array}$ & Substrate & $\begin{array}{c}\text { pH Value Before } \\
\text { Digestion }\end{array}$ & $\begin{array}{c}\mathbf{p H} \text { Value } \\
\text { After } \\
\text { Digestion }\end{array}$ \\
\hline \multirow{3}{*}{$50 \%$} & Hay & 6.7 & 6.8 \\
\cline { 2 - 4 } & Corn & 6.2 & 5.4 \\
\cline { 2 - 4 } & Cow Manure & 8.6 & 7.6 \\
\hline \multirow{3}{*}{$80 \%$} & Hay & 6.9 & 6.9 \\
\cline { 2 - 4 } & Corn & 6.2 & 3.9 \\
\cline { 2 - 4 } & Cow Manure & 8.4 & 7.5 \\
\hline
\end{tabular}

TABLE II: THE TOTAL SOLIDS (TS) BEFORE AND AFTER DIGESTION

\begin{tabular}{|c|c|c|c|}
\hline $\begin{array}{c}\text { Percent of } \\
\text { Solid } \\
\text { Sample by } \\
\text { volume }\end{array}$ & Substrate & Before Digestion & After Digestion \\
\cline { 3 - 4 } & Hay & 53.00 & 83.97 \\
\cline { 2 - 4 } $50 \%$ & Corn & 29.79 & 85.84 \\
\cline { 2 - 4 } & $\begin{array}{c}\text { Cow } \\
\text { Manure }\end{array}$ & 71.90 & 82.30 \\
\hline \multirow{3}{*}{$80 \%$} & Hay & 49.73 & 81.37 \\
\cline { 2 - 4 } & Corn & 40.63 & 86.32 \\
\cline { 2 - 4 } & $\begin{array}{c}\text { Cow } \\
\text { Manure }\end{array}$ & 32.2 & 80.70 \\
\hline
\end{tabular}

TABLE III: THE TOTAL Volatile SOLIDS (VS) BEFORE AND AFTER

\begin{tabular}{|c|c|c|c|}
\multicolumn{4}{|c|}{ DIGESTION } \\
\cline { 3 - 4 } $\begin{array}{c}\text { Percent } \\
\text { of Solid } \\
\text { Sample } \\
\text { by } \\
\text { volume }\end{array}$ & \multirow{2}{*}{ Substrate } & \% Total Volatile Solids (VS) \\
\hline \multirow{3}{*}{$50 \%$} & & Before Digestion & After Digestion \\
\cline { 3 - 4 } & Hay & 78.20 & 40.07 \\
\cline { 2 - 4 } & Corn & 95.94 & 80.98 \\
\hline \multirow{3}{*}{$80 \%$} & Cow Manure & 85.50 & 26.30 \\
\cline { 2 - 4 } & Hay & 94.24 & 43.61 \\
\cline { 2 - 4 } & Corn & 96.18 & 80.98 \\
\hline
\end{tabular}

On the same table above, the $\mathrm{pH}$ values of $50 \%$ and $80 \%$ by volume of Corn and Cow Manure samples before and after digestion decreases ( from slightly basic to slightly acidic ) while the $\mathrm{pH}$ value of the Hay sample of $50 \%$ by volume increases and the $80 \%$ by volume doesn't changed (remains slightly acidic).

The Total Solid and Volatile Solids. The total solids and total volatile solids of $50 \%$ and $80 \%$ by volume samples of Hay, Corn and Cow Manure are shown in Table II and Table
III.

As presented in the table, the total solids on $50 \%$ by volume of hay sample before and after digestion increases from 53 to $83.88 \%$ while the total volatile solids decreases from 78.20 to $40.07 \%$.

The trend was repeated in the digestion of $80 \%$ by volume of the sample. The total solids increases and volatile solids decreases from 49.73 to $81.37 \%$ and 94.24 to $43.41 \%$ respectively.

It appears that $38.13 \%$ has been digested to produce a biogas yield of $50 \%$ by volume and $50.83 \%$ for $80 \%$ by volume of Hay monosubstrate sample.

The Corn sample in the table based on $50 \%$ solid sample by volume also revealed that the sample total solids increases from $29.79 \%$ to $85.84 \%$ before and after digestion, while the volatile solid decreases from 95.94 to $80.98 \%$.

This was repeated in the digestion of $80 \%$ of solid sample by volume. The total solids increases and the volatile solids decreases from 40.63 to $86.32 \%$ and 96.18 to $80.98 \%$ respectively.

It appears that $14.96 \%$ has been digested to produce a biogas yield of $50 \%$ by volume and $15.2 \%$ for $80 \%$ by volume of Corn sample.

For the Cow Manure sample, the table reveals that for $50 \%$ of solid sample by volume, the total solids before and after digestion increases from 71.90 to $82.30 \%$ while the volatile solids decreases from 85.50 to $26.30 \%$.

The trend of $50 \%$ by volume was repeated in the digestion of $80 \%$ by volume of the monosubstrate sample. The total solids increases and volatile solids decreases from $32.20 \%$ to $80.70 \%$ and 75.70 to $29.00 \%$ respectively.

It appears that $59.2 \%$ has been digested to produce a biogas yield of $50 \%$ by volume and $46.7 \%$ for $80 \%$ by volume of Cow manure sample.

The table further reveals that the highest total solid is $86.32 \%$ ( $80 \%$ by volume corn sample) after digestion and the lowest is $29.79 \%$ ( $50 \%$ by volume corn sample) before digestion.

The lowest value of total volatile solids after digestion is $26.30 \%$ (50\% by volume of Cow Manure sample) and the highest is $96.18 \%$ ( $80 \%$ by volume corn) before digestion.

\section{B. Properties of Energy Crops}

The analysis of crude protein, fat and carbohydrates of Hay and Corn as a monosubstrate samples are presented in Table IV.

TABLE IV: THE CRUde PROTEIN (XP), CRUdE FAT (XL) AND CARBOHYDRATES (XF)

\begin{tabular}{lccc}
\hline \hline Substrate & $\begin{array}{c}\text { \%Crude } \\
\text { Protein (XP) }\end{array}$ & $\begin{array}{c}\text { \%Crude } \\
\text { Fat }(\mathbf{X L})\end{array}$ & $\begin{array}{c}\text { \%Carbohydrates } \\
(\mathbf{X F})\end{array}$ \\
\hline Hay & $8.71^{*}$ & $1.66^{*}$ & $76.42^{*}$ \\
Corn & $10.21^{*}$ & $3.75^{*}$ & $78.3^{*}$ \\
Animal & N.A. & N.A. & N.A. \\
Waste & & & \\
\hline \hline
\end{tabular}

* This value is taken from the laboratory analysis results of the Bureau of Plant Industry - Manila, Philippines

As presented, both hay and corn samples have high carbohydrate component $(76.42 \%$ for hay and $78.3 \%$ for corn). Both hay and corn samples contain small percentages of crude protein $(8.71 \%$ for hay and $10.21 \%$ for corn). Both substrates have minimal percentages of crude fat $1.66 \%$ and $3.75 \%$ respectively. 
These means that a greater percentage of the composition of the raw materials used to convert to methane gas was primarily derived from carbohydrates.

\section{Properties of Biogas Yield}

Influent (Solid) and Gas Densities. The densities of the $50 \%$ and $80 \%$ Hay, Corn, and Cow Manure influent substrate and gases are tabulated in Table $\mathrm{V}$.

As presented, the densities of the influent of $50 \%$ by volume for Hay, Corn and Cow Manure range from 290.1 to $363.64 \mathrm{~kg} / \mathrm{m}^{3}$ while the $80 \%$ by volume the densities range from 290.91 to $339.93 \mathrm{~kg} / \mathrm{m}^{3}$. It appears that the mass of the $50 \%$ by volume sample is lighter than the $80 \%$ by volume sample.

However, the densities of $50 \%$ and $80 \%$ by volume of gases of a monosubstrate samples range from 2.26 to 2.34 $\mathrm{kg} / \mathrm{m}^{3}$. This shows that the gas of $50 \%$ by volume samples is lighter than the $80 \%$ by volume samples.

TABLE V: THE DENSITIES OF INFLUENT AND GAS

\begin{tabular}{|c|c|c|c|}
\hline $\begin{array}{c}\text { Percent of } \\
\text { Solid Sample } \\
\text { by volume }\end{array}$ & Substrate & $\begin{array}{c}\text { Influent Substrate } \\
\text { Density in } \mathrm{kg} / \mathrm{m}^{3}\end{array}$ & $\begin{array}{c}\text { Density of the } \\
\text { gas in } \mathrm{kg} / \mathrm{m}^{3}\end{array}$ \\
\hline \multirow{3}{*}{$50 \%$} & Hay & 290.91 & 2.34 \\
\hline & Corn & 363.64 & 2.34 \\
\hline & $\begin{array}{c}\text { Cow } \\
\text { Manure }\end{array}$ & 363.64 & 2.31 \\
\hline \multirow{3}{*}{$80 \%$} & Hay & 290.91 & 2.34 \\
\hline & Corn & 339.39 & 2.26 \\
\hline & $\begin{array}{c}\text { Cow } \\
\text { Manure }\end{array}$ & 339.39 & 2.31 \\
\hline
\end{tabular}

\section{Percent Composition of Methane and Carbon Dioxide} towards Temperature and Time

Concentration of Methane vs. Carbon Dioxide. The digestion of Hay, Corn and Cow Manure of $50 \%$ and $80 \%$ by volume in relation to carbon dioxide concentrations are presented in the Fig. 6 and Fig. 7.

In Fig. 6 and Fig. 7, the concentrations of carbon dioxide started to rise after few days of digestion of $50 \%$ and $80 \%$ by volume Hay, Corn and Cow manure samples. These indicate that the oxygen gas incorporated in the system before digestion has been used to oxidize the sample to form oxide of carbon. When the oxygen is consumed, the anaerobic condition of the digestion started, and the methane gas started to appear in the monitoring panel.

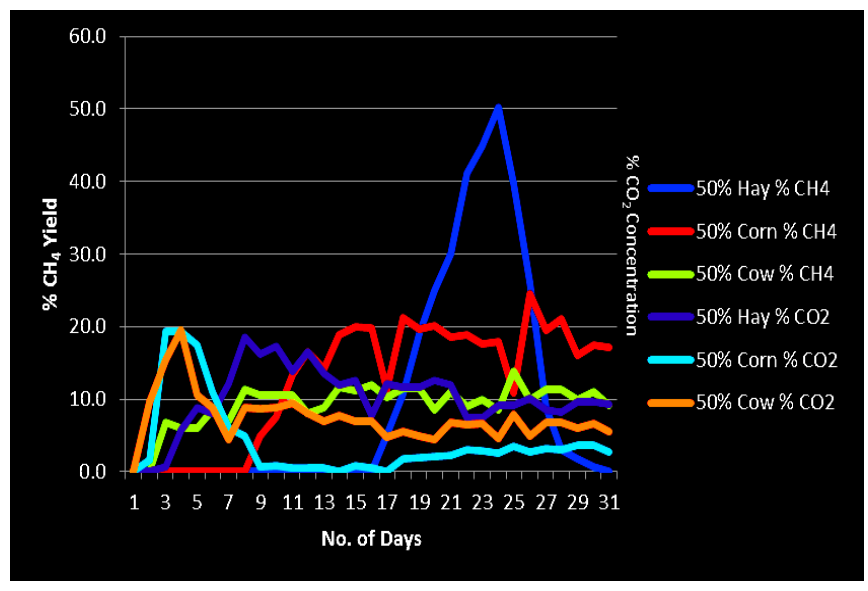

Fig. 6. $\% \mathrm{CH}_{4}$ yield vs. \% CO concentration (@ $50 \%$ by volume digestion).

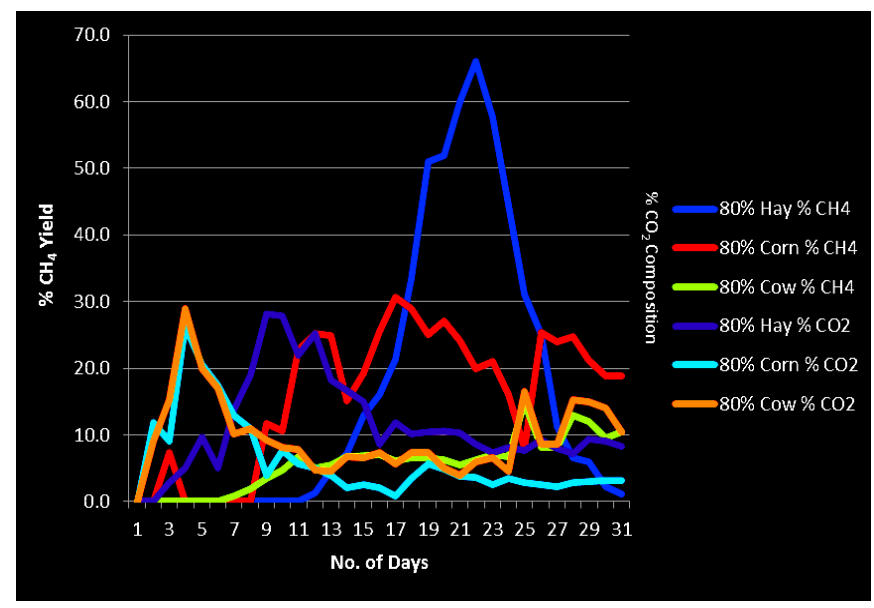

Fig. 7. \% $\mathrm{CH}_{4}$ yield vs. \% CO concentration (@80\% by volume digestion).

Each samples of Hay, Corn and Cow manure as a monosubstrate appeared to yield biogas in an increasing manner until it reaches its peak while the carbon dioxide concentration is constantly decreasing.

The carbon dioxide of both loading concentration of the monosubstrate samples ( $50 \%$ and $80 \%$ by volume) revealed that even concentration decreases, the concentration of carbon dioxide in gas mixture doesn't approaches to zero due to the minimal adsorption of oxygen in air during sampling activity. During sampling period, the little amount of air was allowed to pass through the chamber of digestion by opening the valve control of influent section to allow the gas to flow freely. The fluctuations of the concentration of the carbon dioxide vary depending on the length of time and exposure of the concentrated gas when the chamber is open. The concentration of the methane gas collected during digestion will depend on the digestible materials of Hay, Corn and Cow manure. This digestible concentration is dependent on the total volatile solids and the density of the influent. As discussed on the previous section (Total Solids and Total Volatile Solids), each sample has a varied percentage of the volatile solids that has been digested and converted to form methane gas (one of the biogas component). However, the total volatile solids and density of the influent cannot explain of why the Hay sample of both $50 \%$ and $80 \%$ by volume took the highest yield among the samples digested. The best explanation of this observation is discussed on the concentration of methane gas vs. temperature section.

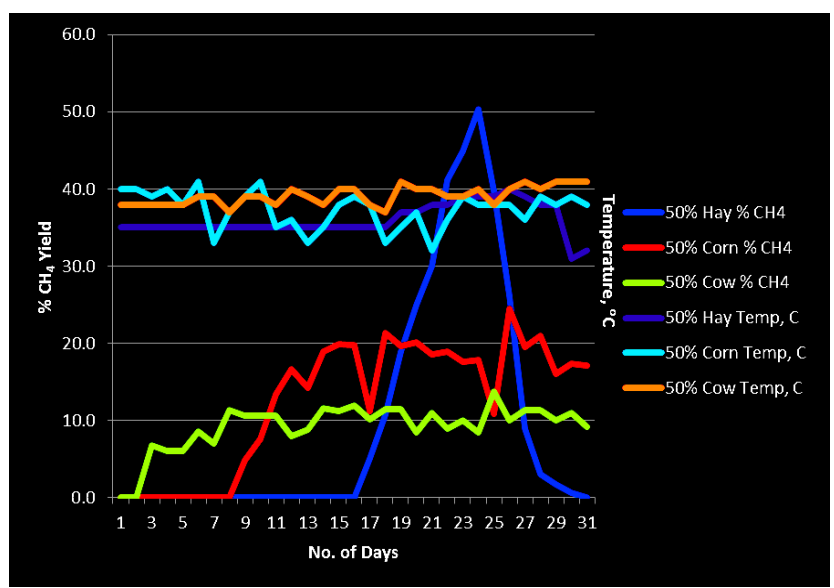

Fig. 8. \% $\mathrm{CH}_{4}$ yield vs. temperature (@50\% by volume digestion). 
Concentration of Methane Gas vs. Temperature. The digestion of Hay, Corn and Cow Manure of $50 \%$ and $80 \%$ by volume in relation to temperature are presented in the Fig. 8 and Fig. 9.

On this figure, only Hay sample temperature started at $35^{\circ} \mathrm{C}$ on the $1^{\text {st }}$ day of digestion and $38^{\circ} \mathrm{C}$ for Corn and Cow manure sample. The figure for these shows that the Hay sample yield is directly affected by the temperature and it revealed to be the highest yield among the rest of the samples of both $50 \%$ and $80 \%$ by volume. The Hay sample was digested during the winter reason which temperature is controlled by temperature controller coupled with thermocouple designed to heat up when the temperature goes down below $35^{\circ} \mathrm{C}$ up to the maximum of $40^{\circ} \mathrm{C}$ (the mesophilic condition). This relationship is also proven and supported at the treatment of result section of this study.

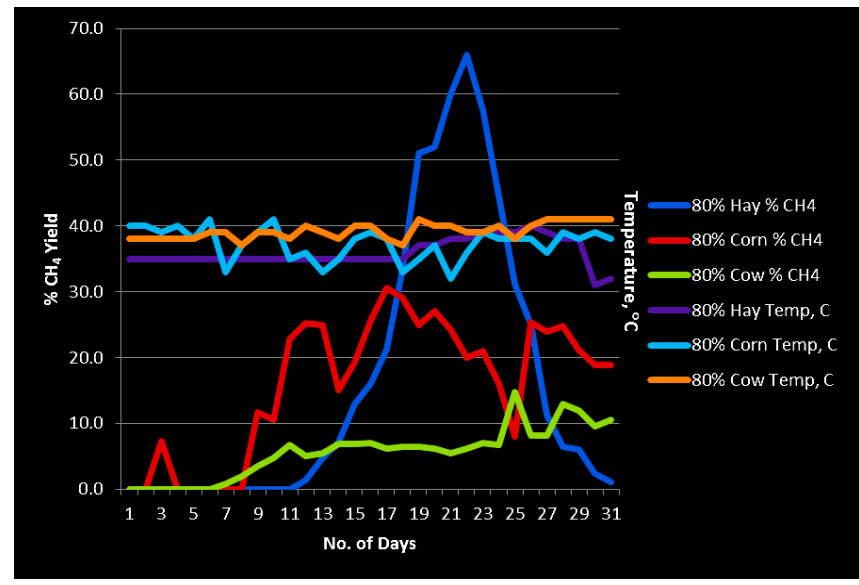

Fig. 9. \% $\mathrm{CH}_{4}$ yield vs. temperature (@ $80 \%$ by volume digestion).

The Corn and Cow manure samples were digested during summer period. That is the reason why the digestion started at temperature higher than $35^{\circ} \mathrm{C}$ and even getting beyond $40^{\circ} \mathrm{C}$.

Although there is a slight difference in the temperature range between the Corn and Cow manure samples, the corn sample yields higher than the Cow manure sample.

While the temperature has direct influence on the yield of the 3 samples, high yields of Corm and Cow manure samples still depends on the quantity of the digestible materials.

The Corn sample of $50 \%$ and $80 \%$ by volume has 363.64 $\mathrm{kg} / \mathrm{m}^{3}(0.75 \mathrm{~kg})$ and $339.39 \mathrm{~kg} / \mathrm{m}^{3}(1.2 \mathrm{~kg})$ while Cow manure has $363.64 \mathrm{~kg} / \mathrm{m}^{3}(0.5 \mathrm{~kg})$ and $339.39 \mathrm{~kg} / \mathrm{m}^{3}(0.7 \mathrm{~kg})$.

TABLE VI: THE REQUIRED No. OF DAYS OF THE MAXIMUM $\% \mathrm{CH}_{4}$ YIELD

\begin{tabular}{|c|c|c|c|c|c|}
\hline $\begin{array}{c}\text { Percent } \\
\text { of Solid } \\
\text { Sample } \\
\text { by } \\
\text { volume }\end{array}$ & Substrate & $\begin{array}{c}\text { The } \\
\text { Required } \\
\text { No. of Day }\end{array}$ & $\begin{array}{c}\text { Peak \% } \\
\text { CH }_{4} \\
\text { Yield }\end{array}$ & $\begin{array}{c}\text { Conc. } \\
\text { Of } \\
\text { CO }_{2}\end{array}$ & Temp \\
\hline \multirow{3}{*}{$50 \%$} & Hay & 24 & 50.3 & 9.2 & 39 \\
\cline { 2 - 6 } & Corn & 26 & 38 & 2.8 & 38 \\
\cline { 2 - 6 } & $\begin{array}{c}\text { Cow } \\
\text { Manure }\end{array}$ & 14 & 11.6 & 7.8 & 38 \\
\hline \multirow{2}{*}{$80 \%$} & Hay & 22 & 66 & 8.6 & 38 \\
\cline { 2 - 6 } & Corn & 17 & 30.6 & 0.9 & 38 \\
\cline { 2 - 6 } & $\begin{array}{c}\text { Cow } \\
\text { Manure }\end{array}$ & 25 & 14.8 & 16.5 & 38 \\
\hline
\end{tabular}

It appears that Corn sample provides more yield than Cow manure sample within the 31 days of digestion. This is because Corn sample has higher density of influent with a higher mass of a digestible matter compared to Cow manure.

Highest yield digestion of Hay, Corn and Cow Manure as a monosubstrate samples of $50 \%$ and $80 \%$ by volume with its corresponding time required to produce high $\% \mathrm{CH}_{4}$ yield, peak of $\% \mathrm{CH}_{4}$ yield, concentration of carbon dioxide, and temperature are presented in Table VI.

As presented, the $50 \%$ by volume of Hay sample started to generate methane gas at the $16^{\text {th }}$ day of digestion and reaches its peak at $24^{\text {th }}$ day of a 31 days digestion while the carbon dioxide gradually decreases its concentration with the temperature fluctuating ranging from 35 to $40{ }^{\circ} \mathrm{C}$ at constant pressure of 1 Atm.

The $50 \%$ by volume Corn sample started to generate methane gas at the $9^{\text {th }}$ day of digestion and reaches its peak at $26^{\text {th }}$ day of a 31 days digestion while the carbon dioxide gradually decreases its concentration with the temperature fluctuating range from 33 to $41{ }^{\circ} \mathrm{C}$ at constant pressure of 1 Atm.

The $50 \%$ by volume Cow Manure sample started to generate methane gas at the $3^{\text {rd }}$ day of digestion and reaches its peak at $25^{\text {th }}$ day of a 31 days digestion while the carbon dioxide gradually decreases its concentration with the temperature fluctuating ranging from 35 to $41^{\circ} \mathrm{C}$ at constant pressure of 1 Atm.

The $80 \%$ by volume Hay sample started to generate methane gas at the $12^{\text {th }}$ day of digestion and reaches its peak at $22^{\text {th }}$ day of a 31 days digestion while the carbon dioxide gradually decreases its concentration with the temperature fluctuating range from 32 to $40{ }^{\circ} \mathrm{C}$ at constant pressure of 1 Atm.

The $80 \%$ by volume Corn sample started to generate methane gas at the $3^{\text {rd }}$ day of digestion and reaches its peak at $17^{\text {th }}$ day of a 31 days digestion while the carbon dioxide gradually decreases its concentration with the temperature fluctuating range from 32 to $41^{\circ} \mathrm{C}$ at constant pressure of 1 Atm.

The $80 \%$ by volume Cow Manure sample started to generate methane gas at the $8^{\text {th }}$ day of digestion and reaches its peak at $25^{\text {th }}$ day of a 31 days digestion while the carbon dioxide gradually decreases its concentration with the temperature fluctuating range from 32 to $41{ }^{\circ} \mathrm{C}$ at constant pressure of 1 Atm.

\section{E. Treatment of Results}

Table VII presents the effects of temperature, pressure, density of substrate, density of gas, $\mathrm{pH}$ value, total solids, total volatile solids and crude proteins, fats and carbohydrates of $50 \%$ and $80 \%$ by volume of a monosubstrate Hay, Corn and Cow manure samples on $\% \mathrm{CH}_{4}$ yield.

TABLE VII: REGRESSION OF $\% \mathrm{CH}_{4}$ YIELD WITH TEMPERATURE AND DENSITY OF THE GAS

\begin{tabular}{|c|c|c|c|}
\hline $\begin{array}{c}\text { Percent of } \\
\text { Solid Sample } \\
\text { by volume }\end{array}$ & Substrate & $\begin{array}{c}\text { Temp, }{ }^{\circ} \mathbf{C} \boldsymbol{R}^{\mathbf{2}} \\
\text { Value }\end{array}$ & $\begin{array}{c}\text { Density of Gas } \\
\boldsymbol{R}^{\mathbf{2}} \text { Value }\end{array}$ \\
\hline \multirow{3}{*}{$50 \%$} & Hay & 0.5333 & 0.5294 \\
\cline { 2 - 4 } & Corn & 0.1291 & 0.1271 \\
\cline { 2 - 4 } & Cow Manure & 0.0705 & 0.0702 \\
\hline \multirow{2}{*}{$80 \%$} & Hay & 0.3697 & 0.3685 \\
\cline { 2 - 4 } & Corn & 0.1638 & 0.1187 \\
\cline { 2 - 4 } & Cow Manure & 0.2852 & 0.2841 \\
\hline
\end{tabular}


The table further reveals the coefficients of determination when $\% \mathrm{CH}_{4}$ yield of biogas is regressed with the independent variables. Note: Only variables found to be significant predictors of $\% \mathrm{CH}_{4}$ yield are presented in the table (temperature and the density of the gas). It appears that both temperature and density of the gas on Hay sample provides the greatest predicting power for $\% \mathrm{CH}_{4}$ yield among the substrates but decreases as percent of solid sample by volume is increased. The figures suggest that 53.33 percent and 52.94 percent in the variations of $\% \mathrm{CH}_{4}$ yield can be attributed to temperature and density of the gas respectively for $50 \%$ of solid sample by volume while only 36.97 percent and 36.85 percent of the variations in $\% \mathrm{CH}_{4}$ yield can be accounted from the temperature and density of the gas with $80 \%$ solid sample by volume.

$\% \mathrm{CH}_{4}$ Yield as a Function of $\mathrm{CO}_{2}$. Table VIII presents the regression of $\% \mathrm{CH}_{4}$ yield with Carbon Dioxide $\left(\mathrm{CO}_{2}\right)$. The table further shows that for $50 \%$ by volume of solid sample Carbon dioxide for Hay and Corn appears to be inversely correlated to the $\% \mathrm{CH}_{4}$ yield. This is manifested by the negative coefficient equivalent to -0.0695 (Hay), and -0.05615 (Corn) respectively.

TABLE VIII: SigNifiCANT CORRELATION OF \% $\mathrm{CH}_{4}$ YIELD AS A

\begin{tabular}{|c|c|c|c|c|}
\hline \multirow{2}{*}{$\begin{array}{c}\text { Percent } \\
\text { by } \\
\text { volume }\end{array}$} & Substrate & \multicolumn{3}{|c|}{ As a Function of \% CO $\mathbf{C O}_{\mathbf{2}}$} \\
\cline { 2 - 5 } & $\left(^{\mathbf{2}}\right)$ & $(\boldsymbol{R})$ & $\begin{array}{c}\boldsymbol{P} \text { Value } \\
(\boldsymbol{\alpha}=\mathbf{0 . 0 5})\end{array}$ \\
\hline \multirow{3}{*}{$50 \%$} & Hay & 0.0048 & -0.0695 & 0.0000 \\
\cline { 2 - 5 } & Corn & 0.3153 & -0.05615 & 0.0008 \\
\cline { 2 - 5 } & $\begin{array}{c}\text { Cow } \\
\text { Manure }\end{array}$ & 0.0043 & -0.0656 & 0.7213 \\
\hline \multirow{3}{*}{$80 \%$} & Hay & 0.0389 & -0.01971 & 0.2971 \\
\cline { 2 - 5 } & Corn & 0.4709 & -.06862 & 0.00001 \\
\cline { 2 - 5 } & $\begin{array}{c}\text { Cow } \\
\text { Manure }\end{array}$ & 0.0079 & -0.0888 & 0.6290 \\
\hline
\end{tabular}

This is significant relationship yield to a coefficient of determination equivalent to 0.3153 which further implies that $31.53 \%$ of the amount in variation of $\mathrm{CH}_{4}$ yield can be attributed to Carbon dioxide; considering that as the Carbon dioxide decreases, the $\% \mathrm{CH}_{4}$ yield likewise increases. Both Hay and Corn appeared to be highly significant at 0.000 and 0.0008 respectively.

Table VIII shows that $80 \%$ by volume solid sample Carbon dioxide for Corn appears to be directly correlated to the $\% \mathrm{CH}_{4}$ yield. This is manifested by the negative coefficient equivalent to -0.06862 (Corn). Only Corn appeared to be highly significant at 0.00001 .

This is significant relationship yield to a coefficient of determination equivalent to 0.4709 which further implies that $47.09 \%$ of the amount in variation of $\mathrm{CH}_{4}$ yield can be attributed to the variation of Carbon dioxide; considering that as that as the Carbon dioxide decreases, the $\% \mathrm{CH}_{4}$ yield likewise increases.

$\% \mathrm{CH}_{4}$ Yield as a Function of Temperature. Table IX presents the coefficient of correlation and determination of $\%$ $\mathrm{CH}_{4}$ yield as a function of temperature. The table further shows that for a $50 \%$ by volume of solid sample temperature for Hay and Cow manure appears to be directly correlated to the $\% \mathrm{CH}_{4}$ yield. This is manifested by the positive correlation coefficient equivalent to 0.7303 (Hay) and 0.2656 (Cow manure) respectively. Only Hay however appeared to be highly significant at 0.000002 .

TABLE IX: SignificANT CORRELATION OF $\% \mathrm{CH}_{4}$ YiELD AS A FUNCTION OF TEMPERATURE

\begin{tabular}{|c|c|c|c|c|}
\hline \multirow{2}{*}{$\begin{array}{c}\text { Percent } \\
\text { by } \\
\text { volume }\end{array}$} & Substrate & \multicolumn{2}{|c|}{ As a Function of Temperature } \\
\cline { 3 - 5 } & & $\left(\boldsymbol{R}^{\mathbf{2}}\right)$ & $(\boldsymbol{R})$ & $\begin{array}{c}\boldsymbol{P} \text { Value } \\
(\boldsymbol{\alpha}=\mathbf{0 . 0 5})\end{array}$ \\
\hline \multirow{3}{*}{$50 \%$} & Hay & 0.5333 & 0.7303 & 0.000002 \\
\cline { 2 - 5 } & Corn & 0.1291 & -0.3593 & 0.0434 \\
\cline { 2 - 5 } & Cow Manure & 0.0705 & 0.2656 & 0.1218 \\
\hline \multirow{3}{*}{$80 \%$} & Hay & 0.3697 & 0.6080 & 0.0002 \\
\cline { 2 - 5 } & Corn & 0.1638 & -0.4047 & 0.0216 \\
\cline { 2 - 5 } & Cow Manure & 0.2852 & 0.5340 & 0.0016 \\
\hline
\end{tabular}

This significant relationship yield to a coefficient of determination equivalent to 0.533 which further implies that 53.33 percent of the amount in variation of $\% \mathrm{CH}_{4}$ yield can be attributed to the variation of temperature; considering that as the temperature rises, the $\% \mathrm{CH}_{4}$ yield likewise increases.

And the table shows that for $80 \%$ by volume of solid sample temperature for Hay, Corn and Cow manure appears to be directly correlated to the $\% \mathrm{CH}_{4}$ yield. This is manifested by the positive correlation equivalent to 0.6080 (Hay) and 0.5340 (Cow manure) respectively. Both Hay and Cow manure appeared to be highly significant at 0.0002 and 0.0016 respectively.

This significant relationship yield to a coefficient of determination equivalent to 0.3697 which further implies that 37.97 percent of a the amount in variation of $\% \mathrm{CH}_{4}$ yield can be attributed to the variation of temperature; considering that as the temperature rises, the $\% \mathrm{CH}_{4}$ yield likewise increases.

$\% \mathrm{CH}_{4}$ Yield as a Function of Gas Density. Table X presents the coefficient of correlation and determination of $\% \mathrm{CH}_{4}$ yield as a function of gas density. The table further shows for a $50 \%$ by volume of solid sample gas density for Hay and Corn appears to be directly correlated to the $\% \mathrm{CH}_{4}$ yield. This is manifested by the positive correlation coefficient equivalent to 0.7276 and 0.3564 respectively. Only Hay appeared to be highly significant at 0.000002 .

This significant relationship yield to a coefficient of determination equivalent to 0.5294 which further implies that $52.94 \%$ of the amount in variation of $\% \mathrm{CH}_{4}$ can be attributed to the variation of gas density; considering that as the gas density rises, the $\% \mathrm{CH}_{4}$ yield likewise increases.

TABLE X: SigNifiCANT CORRELATION OF \% YIELD CH4 AS A FUNCTION OF GAS DENSITY

\begin{tabular}{|c|c|c|c|c|}
\hline \multirow{2}{*}{$\begin{array}{c}\text { Percent } \\
\text { by } \\
\text { volume }\end{array}$} & Substrate & \multicolumn{3}{|c|}{ As a function of Gas Density } \\
\cline { 3 - 5 } & & $\left(\boldsymbol{R}^{\mathbf{2}}\right.$ & $(\boldsymbol{R})$ & $\begin{array}{c}\boldsymbol{P} \text { Value } \\
(\boldsymbol{\alpha}=\mathbf{0 . 0 5})\end{array}$ \\
\hline \multirow{3}{*}{$50 \%$} & Hay & 0.5294 & 0.7276 & 0.000002 \\
\cline { 2 - 5 } & Corn & 0.1271 & 0.3564 & 0.0452 \\
\cline { 2 - 5 } & Cow Manure & 0.0702 & -0.2649 & 0.1428 \\
\hline \multirow{3}{*}{$80 \%$} & Hay & 0.3685 & 0.6071 & 0.0002 \\
\cline { 2 - 5 } & Corn & 0.1187 & 0.3445 & 0.0535 \\
\cline { 2 - 5 } & Cow Manure & 0.2841 & -0.5330 & 0.0017 \\
\hline
\end{tabular}

And the table shows for $80 \%$ by volume of solid sample gas density for Hay and Corn appears to be directly correlated to the $\% \mathrm{CH}_{4}$ yield. This is manifested by the positive correlation coefficient equivalent to 0.6071 and 0.3445 respectively. Only Hay appeared to be highly significant at $0.0002 . \% \mathrm{CH}_{4}$ Yield as a Function of Time. Table XI presents the coefficient of correlation and determination of $\% \mathrm{CH}_{4}$ yield as a function of time. The table further shows that for a $50 \%$ by volume of solid sample time for Hay, Corn and Cow 
manure appears to be directly correlated to the $\% \mathrm{CH}_{4}$ yield. This is manifested by the positive correlation coefficient equivalent to 0.4580 (Hay), 0.7690 (Corn) and 0.5762 (Cow manure) respectively. Only Corn however appeared to be highly significant at 0.0000003 .

And the table shows that $80 \%$ by volume of solid sample time for Hay, Corn and Cow manure appears to be directly correlated to the $\% \mathrm{CH}_{4}$ yield. This is manifested by the positive correlation coefficient equivalent to 0.4395 (Hay), 0.7690 (Corn) and 0.5762 (Cow Manure) respectively. Both Corn and Cow manure however appeared to be highly significant at 0.00008 and 0.0000 respectively.

TABLE XI: SIGNIFICANT CORRELATION OF \% YIELD $\mathrm{CH}_{4}$ AS A FUNCTION OF TIME

\begin{tabular}{|c|c|c|c|c|}
\hline \multirow{2}{*}{$\begin{array}{c}\text { Percent } \\
\text { by } \\
\text { volume }\end{array}$} & Substrate & \multicolumn{3}{|c|}{ As a function of Time } \\
\cline { 3 - 5 } & & $\left(\boldsymbol{R}^{\mathbf{2}}\right)$ & $(\boldsymbol{R})$ & $\begin{array}{c}\boldsymbol{P} \text { Value } \\
(\boldsymbol{\alpha}=\mathbf{0 . 0 5})\end{array}$ \\
\hline \multirow{3}{*}{$50 \%$} & Hay & 0.2098 & 0.4580 & 0.0084 \\
\cline { 2 - 5 } & Corn & 0.5913 & 0.7690 & 0.0000003 \\
\cline { 2 - 5 } & Cow Manure & 0.3320 & 0.5762 & 0.0006 \\
\hline \multirow{3}{*}{$80 \%$} & Hay & 0.1931 & 0.4395 & 0.0118 \\
\cline { 2 - 5 } & Corn & 0.4091 & 0.6396 & 0.00008 \\
\cline { 2 - 5 } & Cow Manure & 0.7298 & 0.8543 & 0.0000 \\
\hline
\end{tabular}

This significant relationship yield to a coefficient of determination equivalent to 0.7298 which further implies that 72.98 percent of the amount in variation of $\% \mathrm{CH}_{4}$ yield can be attributed to the variation of time; considering that as the time progresses, the $\% \mathrm{CH}_{4}$ yield likewise increases.

Prediction of the Order of Kinetics. In plotting the density of gas, LN of gas density and the fraction of gas density versus the time on this study predict the actual order of the reactions kinetics of Hay, Corn and Cow Manure after 31 days of digestions.

The prediction of the order of kinetics of $50 \%$ and $80 \%$ by volume of Hay, Corn and Cow manure monosubstrate can be visualized in the graph that is shown in the Appendix I.

However, it is easier to decide the order of reaction by considering the degree of correlation of $\%$ yield $\mathrm{CH}_{4}$ as a function of time expressed in coefficient of determination which is shown in Table XII.

It is revealed on this table (numbers in red color) that $50 \%$ and $80 \%$ by volume of Hay, Corn and Cow manure monosubstrate samples are in favour to the fraction of the gas density. These would mean that the reaction of the production of biogas follows the second order of reaction kinetics.

\begin{tabular}{|c|c|c|c|}
\multicolumn{4}{c|}{ TABLE XII: THE ORDER OF REACTION KINETICS } \\
\hline \multirow{3}{*}{$\begin{array}{c}\text { Percent } \\
\text { by } \\
\text { volume }\end{array}$} & \multirow{2}{*}{ Substrate } & $\begin{array}{c}\text { Zeroth order } \mathbf{~}^{\text {st }} \\
\text { Order }\left(\boldsymbol{R}^{\mathbf{2}}\right)\end{array}$ & $\mathbf{2}^{\text {nd }}$ order $\left(\boldsymbol{R}^{\mathbf{2}}\right)$ \\
\cline { 3 - 4 } & & $\begin{array}{c}\text { Gas Density vs } \\
\text { Time [LN Gas vs } \\
\text { Time] }\end{array}$ & 1/Gas Density \\
\hline \multirow{3}{*}{$50 \%$} & Hay & $0.1225[0.1245]$ & 0.1265 \\
\cline { 2 - 4 } & Corn & $0.0317[0.0323]$ & 0.0330 \\
\cline { 2 - 4 } & Cow Manure & $0.4006[04010]$ & 0.4015 \\
\hline \multirow{3}{*}{$80 \%$} & Hay & $0.1225[0.1245]$ & 0.1265 \\
\cline { 2 - 4 } & Corn & $0.0014[0.0015]$ & 0.0016 \\
\cline { 2 - 4 } & Cow Manure & $0.4203[04208]$ & 0.4212 \\
\hline
\end{tabular}

\section{F. Modeling of Biogas Yield}

Based on the mass balance equation of substrate in a batch reaction with a constant volume for a steady state, the input of every component equals the sum of removal and substrate degradation. The biogas occurs both from the degraded fresh material and especially from the biodegradable organic matter. Therefore, the mass of biogas, $m_{g}$ can be expressed as the difference between the mass input, $m_{i n}$ and the mass of effluent, $m_{\text {out }}$ (Equation 1).

$$
m_{g}-m_{\text {in }}-m_{\text {out }}=0
$$

Also, $m_{g}$ corresponds to the difference between the supplied and the decomposed organic matter. Therefore, the supplied organic matter is the product of $m_{i n}$ and density of the influent (solid). Equally, the removed organic matter is the product of $m_{\text {out }}$ and the density of the influent (solid) after digestion (Equation 2).

$$
m_{g} \rho_{g}-m_{\text {in }} \rho_{\text {in }}-m_{\text {out }} \rho_{\text {out }}=0
$$

Assuming that the degradation of substrate in a in batch process follows a gas removal rate $\left(r_{g}\right)$ which depends on the concentration at a steady state concentration in the reactor, $\mathrm{m}_{\mathrm{g}}$ corresponds to the gas product rate $\left(r_{g}\right)$ and the time $(t)$ of digestion (Equation 3).

$$
m_{g}=V_{\text {ractor } .} . r_{g}
$$

If $r_{g}$ follows a second-order reaction with a reaction rate constant $k$ as shown Equation 4 and $m_{g}$ can be written as follows (Equation 5)

$$
\begin{gathered}
r_{g}=k(y)^{2} \\
m_{g}=V_{\text {reactor }} t . k(y)
\end{gathered}
$$

Besides, $m_{g}$ is the product of volume and density $(y)$ of the daily produced biogas. Therefore, the mass of gas is equal to pressure $(p)$, absolute temperature $(T)$ with its gas constant $(R)$ at ideal condition as shown in Equation 6.

$$
m_{g}=\frac{R M M_{C H} p V_{g}}{R T}
$$

Equating of Equations 6 and 7 to solve for " $y$ " would result to Equation (7).

$$
y=\frac{R M M_{C H} p \cdot V_{g}}{\sqrt{V_{\text {reactor }} \cdot k \cdot t \cdot R \cdot T}}
$$

\section{CONCLUSION}

Based on the findings of the study, the following conclusions were derived: (1) The $\mathrm{pH}$ values of the monosubstrate digestion of 50 and $80 \%$ by volume of Hay, Corn and Cow manure only indicate the acidity and basicity of the digestion medium but it was not significantly affecting the $\% \mathrm{CH}_{4}$ yield; and the total solids value increases and the volatile solids decrease after 31 days of digestion and both was not significantly affecting the $\% \mathrm{CH}_{4}$ yield in both the $50 \%$ and $80 \%$ by volume digestion, (2) Only carbohydrate among the established properties of Hay and Corn monosubstrate appeared to be the main digestible materials in 31 days of digestion but not significantly affecting the $\% \mathrm{CH}_{4}$ yield, (3) The density of solid doesn't affect the $\% \mathrm{CH}_{4}$ yield while the 
density of the gas significantly affects the $\% \mathrm{CH}_{4}$ yields in both $50 \%$ and $80 \%$ by volume digestion; the temperature was under the mesophilic condition and significantly affecting the $\% \mathrm{CH}_{4}$ yield in both $50 \%$ and $80 \%$ by volume digestion; the concentration of the carbon dioxide was indirectly proportional to the production of the biogas in both $50 \%$ and $80 \%$ by volume digestion; the maximum biogas yield was derived based on the significant effect of the density of gas and temperature with time in both $50 \%$ and $80 \%$ by volume digestion; and the number of days required of producing maximum biogas yield was within 14 to 26 days of both 50 and $80 \%$ by volume digestion, (4) The significant effect of density of gas and temperature with $\% \mathrm{CH}_{4}$ yield considering $50 \%$ by volume of Hay and Corn monosubstrate samples and $80 \%$ by volume of Hay, Corn and Cow manure monosubstrate samples provided significant inputs in the development of the model equation following the $2^{\text {nd }}$ order reaction.

\section{ACKNOWLEDGMENT}

S.T. Sepe, M.A. Baccay, B.A. Jibril and Y. M. Al-Wahaibi extend their thanks to the Department of Petroleum and Chemical Engineering of Sultan Qaboos University, Department of Engineering of Ibra College of Technology, Sultanate of Oman and the Philippines Women's University Manila, Philippines for sponsoring, providing workshop and laboratory facilities for the fabrication of the biodigester including the process of experimentation.

\section{REFERENCES}

[1] T. Amon, B. Amon, V. Kryvoruchko, W. Zollitsch, K. Mayer, and L. Gruber, "Biogas production from maize and dairy cattle manure -
Influence of biomass composition on the methane yield," Agric Ecosystems and Environ, vol. 118, pp. 173-182, 2007.

[2] United Nation - Economic and Social Commission for Asia and the Pacific. 1980. Guidebook on Biogas Development. Energy Development Series No. 21. United National - Economic and Social Commission for Asia and the Pacific, Bangkok, Thailand.

[3] CHP | Combined Heat and Power | Cogeneration | Wood Biomass Gasified Co-generation | Energy Efficiency | Electricity Generation 2010-02-21.

[4] A. C. Wilkie, "Anaerobic digestion of dairy manure: design and process considerations," in Dairy Manure Management: Treatment, Handling, and Community Relations, Natural Resource, Agriculture, and Engineering Service, Cornell University, Ithaca, New York, NRAES-176, pp. 301-312, 2005.

[5] T. W. Widodo, A. Asari, A. Nurhasanah, and E. Rahmarestia, "Biogas Technology Development for Small Scale Cattle Farm Level in Indonesia," in Proc. International Seminar on Development in Biofuel Production and Biomass Technology, Jakarta, 21-22 February 2006.

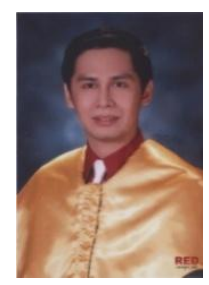

Sherwin T. Sepe is a member of IAENG, and CBEES. A Filipino citizen who is presently working in the Sultanate of Oman. The author graduated a doctor of Technology at the Technological University of the Philippines, Manila couple of years ago with the specialization of Chemical Technology. He is recently a lecturer in Chemistry at the German University of Technology - Oman. He is an experienced teacher in Chemistry and Chemical Engineering related fields in various Universities. He was a dynamic and output oriented Laboratory Supervisor in the Philippines and a productive Pollution Control Officer in the Philippines Women's University, Manila. He is currently working on chemical technology related studies which will be published soon.

Dr. Sherwin T. Sepe is also a member of the Philippine Society of Chemistry Teachers (PACT) and Society of Petroleum Engineers (SPE) Oman Chapter together with the other prestigious engineering societies around the world. 